\title{
Breast Cancer pN3 TNM Finding v8
}

National Cancer Institute

\section{Source}

National Cancer Institute. Breast CancerpN3 TNM Finding v8. NCI Thesaurus. Code C139441.

Breast cancer with metastases in 10 or more axillary lymph nodes; or in infraclavicular (level III axillary) lymph nodes; or positive ipsilateral internal mammary lymph nodes by imaging in the presence of one or more positive level I, II axillary lymph nodes; or in more than three axillary lymph nodes and micrometastases or macrometastases by sentinel lymph node biopsy in clinically negative ipsilateral internal mammary lymph nodes; or in ipsilateral supraclavicular lymph nodes. (from AJCC 8th Ed.) 